Revue

d'ethnoécologie

\section{Revue d'ethnoécologie}

$20 \mid 2021$

Un siècle d'ethno-machins : le centenaire de la Revue de Botanique Appliquée

\title{
A Review of Japanese Ecological Anthropology on Central African Hunter-gatherers
}

Revue de l'anthropologie de l'environnement japonaise sur les chasseurs-

cueilleurs d'Afrique centrale

\section{Mitsuo Ichikawa}

\section{(2) OpenEdition}

\section{Journals}

Electronic version

URL: https://journals.openedition.org/ethnoecologie/8401

DOI: 10.4000/ethnoecologie.8401

ISSN: 2267-2419

\section{Publisher}

Laboratoire Éco-anthropologie

\section{Electronic reference}

Mitsuo Ichikawa, "A Review of Japanese Ecological Anthropology on Central African Huntergatherers", Revue d'ethnoécologie [Online], 20 | 2021, Online since 31 December 2021, connection on 06 March 2022. URL: http://journals.openedition.org/ethnoecologie/8401 ; DOI: https://doi.org/10.4000/ ethnoecologie.8401

This text was automatically generated on 6 March 2022.

\section{cc) (1)}

Revue d'ethnoécologie est mis à disposition selon les termes de la licence Creative Commons Attribution - Pas d'Utilisation Commerciale - Pas de Modification 4.0 International. 


\section{A Review of Japanese Ecological Anthropology on Central African Hunter-gatherers}

Revue de l'anthropologie de l'environnement japonaise sur les chasseurscueilleurs d'Afrique centrale

Mitsuo Ichikawa

\section{INTRODUCTION}

1 Since early 1970s, we have been studying the hunter-gatherers in various parts of central African forest areas. We first made a series of anthropological studies of the Mbuti and Efe hunter-gatherers in the Ituri Forest of DRC (Democratic Republic of Congo, former Zaire) from 1972 to 1990. The initial studies mainly focused on subsistence ecology, in particular hunting activities adapted to the forest environment (Harako 1976, Tanno 1976, Ichikawa 1983, Terashima 1983), plant utilization (Tanno 1981), and social organization (Tanno 1976, Ichikawa 1978, Terashima 1985). When the political situation of former Zaire deteriorated in 1991, we left Zaire for the Republic of Congo (Congo-Brazaville) on the opposite side of the Congo River and began studies on the Aka hunter-gatherers in the Likouala Region of northern Congo-Brazzaville. In 1993, when Congo-Brazzaville also became unstable under a state of internal war, we moved again further west, to the southeastern part of Cameroon, where we have been studying the Baka hunter-gatherers, as well as Bantu-speaking and other cultivators living in the same area. Thus, during the past five decades, we have eventually studied all the three major hunter-gatherer groups in central Africa, the Mbuti and Efe in the eastern part of the Congo Basin, and the Aka and Baka in the western part (Figure 1), as well as the shifting cultivators on eastern and western sides of the central African forests. 
Figure 1 : Major groups of central African hunter-gatherers studied by Japanese anthropologists

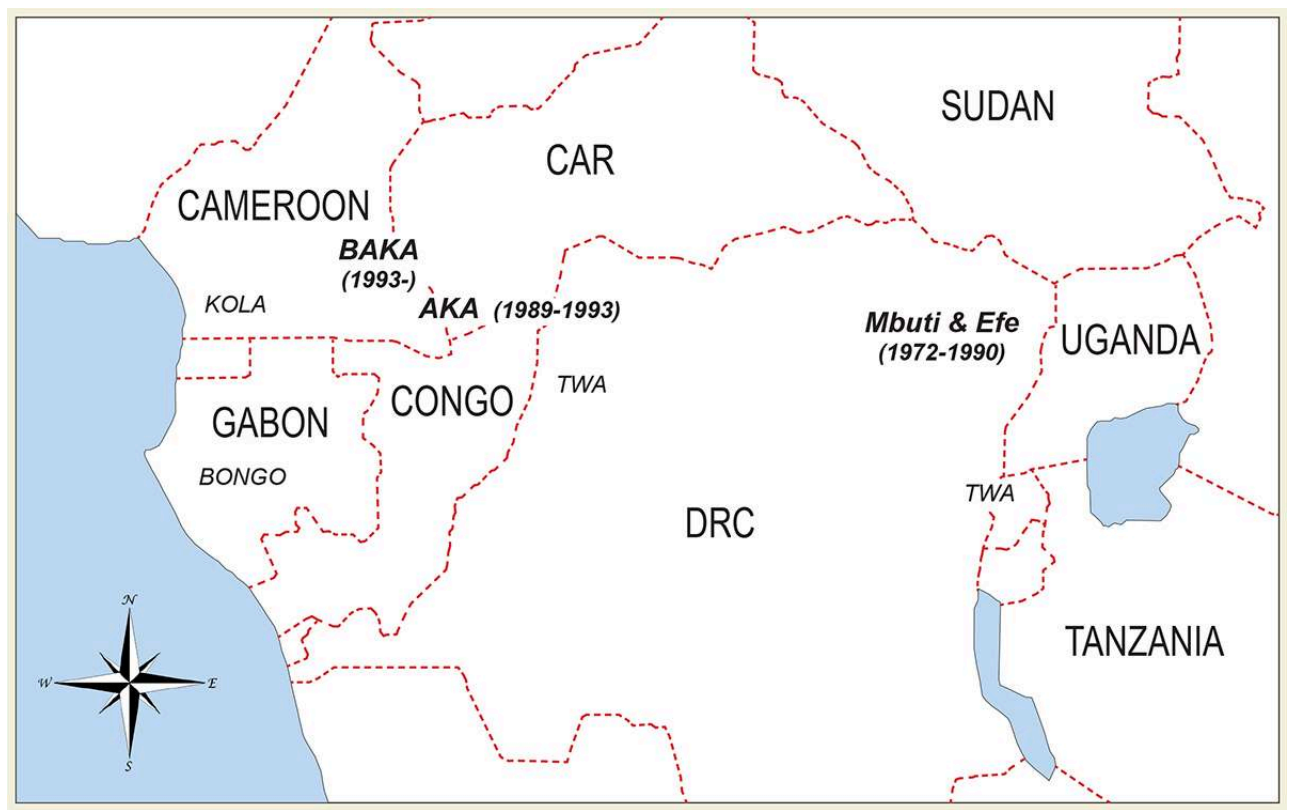

2 These forest peoples ${ }^{1}$ are facing today serious problems concerning their culture and environment. In the Ituri forest of northeastern DRC, they have been suffering from prolonged political unrest since the 1990s in a state of internal war that is fueled by rich mineral resources in the region. In northern Congo-Brazzaville and Cameroon, large-scale logging operations have been accelerating since the 1980s, destroying the forests that have long accommodated their unique forest-based culture. The waves of market economy and consumerism have today reached to the remotest parts of the forest, stimulating the people to change their life, and to exploit forest resources for short-term benefits beyond sustainable levels. Excessive hunting for bushmeat, for example, is depleting the animal resource base, making the remaining forest almost "empty" (Redford 1992) in some areas. Against these destructive impacts on the forest environment, there are also growing international interest in, and movements toward, forest conservation, in which extractive activities in the protected areas are restricted. Owing to these impacts imposed by external forces, the forest peoples in this region are rapidly incorporated into, then marginalized in the system of a broader world, on national and international levels. The bases of their unique culture are threatened in this process by these external forces from outside which also acts on the society internally.

Under such circumstances, it is important to understand the life of forest peoples in local ecological settings, as well as in a wider economic and political context. The desirable way to coping with the threats and changed situation is to re-evaluate and exploit the potentials of "what is already there, » rather than to hastily introduce foreign ideas and technology. From this standpoint, I will examine here the relationships of the local peoples with the forest environment, and with a larger economic system, based on the anthropological research conducted by Japanese researchers during the past five decades.

4 The first problem is that we still have much more to learn about the ecological potentials of the forest for human life, and how people depend on the forest and its resources. Forest peoples have surprisingly rich knowledge about the forest fauna and 
flora, which we can already appreciate if we only walk with them for an hour in the forest. Our first problem is, therefore, cultural ecology; that is, to describe such a unique culture based on the rich knowledge of forest. This approach also shows the diverse cultural potentials of the forests in central Africa.

The second problem is that of historical ecology; that is, the history of interaction between people and forest environments. While the central African hunter-gatherers heavily depend on the forests and their resources, the forests are, in a sense, historical products, maintained through various forms of human interventions, both intentional and non-intentional. In a sense, forests and the people living there are supporting each other. It is important, therefore, to examine the forest environment from a viewpoint of (historical) interactions between humans and the environment.

The inter-dependent system of humans and forest is, however, no longer isolated from other parts of the world; the people today have contacts, more or less, with economic and political systems of a wider society. Therefore, the third problem concerns political ecology; that is, to understand the hunting and gathering life in a wider perspective, in relation to political and economic systems of national as well as international levels. There are various problems involved in this relationship, particularly in the economic and political difficulties that central African countries are facing today. I will present some of the examples that we witnessed in DRC to show how the forest people were coping with an unstable and deteriorating national economy in the 1970s and 1980s. I will also show some of the important findings from our recent international scientific cooperation project in Cameroon, which aimed at combining the local people's welfare and forest conservation through sustainable use and commercialization of non-timber forest products (NTFPs).

\section{Cultural Ecology: Forest as Source of Cultural Values}

\section{Rich indigenous knowledge of forest plants}

7 While there are many aspects of human relationships with the forest world, one of the best ways to illustrate these diverse and multiple relationships is to examine the use of forest plants. Just a brief glance at a forest camp of hunter-gatherers will give us an idea how important are the roles that plants play in their life, as food, medicine and other materials of life. We were impressed by this fact in the initial stage of our research and collected about 1200 plant specimens in the Ituri forest of DRC, along with their vernacular names, and information on their uses and other ethnobotanical information. I will first show the brief results of this study (Tanno 1981, Terashima \& Ichikawa 2003).

8 First, the plants are used for food. While almost 60 to 70 percent of their present diet is comprised of cassava, plantain and other agricultural crops, hunter-gatherers still use more than 100 species for food, out of approximately 750 species collected in the study area (Terashima \& Ichikawa 2003). These include various nuts with high lipid contents, such as those of Irvingia spp. and Ricinodendron, that are widely used in central Africa as oily condiments in pot-au-feu style cooking. Energy-rich starchy food like Canarium schweinfurthii and wild yams (Dioscorea spp.) are eagerly collected, and the sweet and sour fruits of Landolphia spp., Annonidium mannii, and Aframomum spp. are also frequently eaten. 
Many plants in tropical rain forest accumulate various toxic secondary compounds, some of which, if administered properly, could be used as medicine for curing diseases, or as poison for hunting and fishing. About 200 species have so far been recorded as being used for such purposes. Also important is the use of plants for material culture, with about 350 species so far recorded in the Ituri Forest. The traditional material culture of hunter-gatherers is simple, consisting of fewer than 100 items in total (Tanno 1981), including small semi-spherical huts and simple beds made of wooden poles, tools for hunting, gathering, transporting, cooking and dining, as well as for dress and decoration. Of these, more than 80 percent are made, either totally or in part, of plant materials that are abundant in the forest.

In addition to the plants directly used, hundreds of plants are useful in indirect ways, as nectar sources and food of animals that are hunted, fished and collected by the people. Hunter-gatherers have precise knowledge of the food plants of wild animals, and ambush the animals that approach to feed on the plants in their fruiting seasons. While many of the high trees have no direct use, they are important sources of honey, highly prized food as a concentrated natural sweet. They also like to eat various insects feeding on the forest plants.

11 Many of these plants are used in multiple ways. The large leaves of Marantaceae plants provide a good example (Terashima \& Ichikawa 2003, see also Hattori [2006] for the use of Marantaceae plants by the Baka). The seeds of some species (such as Megaphrynium macrostachyum) are eaten roasted, and the skins of long petiocles or stems (of Marantochloa spp.) are used for binding and weaving baskets and mats. The leaves are used for thatching, wrapping, making sleeping mats, cooking and for many other purposes. One of the common local recipes is liboke: fish or livers of game meat, mushrooms or other food are wrapped with the large Marantaceae leaves, mixed with palm oil, salt and red pepper, and cooked in the hot ashes. The leaves add an excellent flavor to the food.

12 The Mbuti believe that the forest is imbued with a supernatural being called Apakumandura, literally meaning the "father of forest ", who controls all the life in the forest. They attribute continued failure in hunting to the deed of Apakumandura, saying that he has made the forest « cool » or « closed. » There is a plant species called akobisi (Uvariopsis congolana, belonging to Annonaceae), that is the visible agent of Apakumandura, and it is strictly forbidden to cut or break this tree (Ichikawa 1996).

Thus, the plants are used, both directly and indirectly, for material as well as spiritual purposes. While most of these plants have little or no commercial value, except those mentioned later, they are indispensable to maintaining the life and culture of huntergatherers. The forest plants also provide the people with the basis of their cultural identity. The destruction of forest, therefore, would result in the deterioration of the culture, which is heavily dependent on the forest.

The rich ethnobotanical knowledge of the forest people represents a cultural heritage that has been accumulated over centuries. It is necessary to preserve such knowledge and to understand the diverse potentials of the tropical rain forest. From such a viewpoint, we have constructed a database, called "Aflora," which aims at compiling information on traditional knowledge of plants in tropical Africa. For each specimen collected in the field, botanical as well as ethnographic information is recorded and put into a computer, using the Aflora information format (Aflora Committee 1987, Ichikawa et al. 2001, Terashima \& Ichikawa 2003, see also Figure 2). This database, we hope, 
facilitates quick reference for specific taxa or usage types, or to obtain a general view of the plant use in a particular area. We have accumulated the data for about 1,200 specimens from the Ituri Forest, and similar ethnobotanical information was uploaded onto the same database on the Aka in northern Congo and the Baka (Hattori 2006, 2007) in eastern Cameroon.

Figure 2 : Aflora information format and the search screen
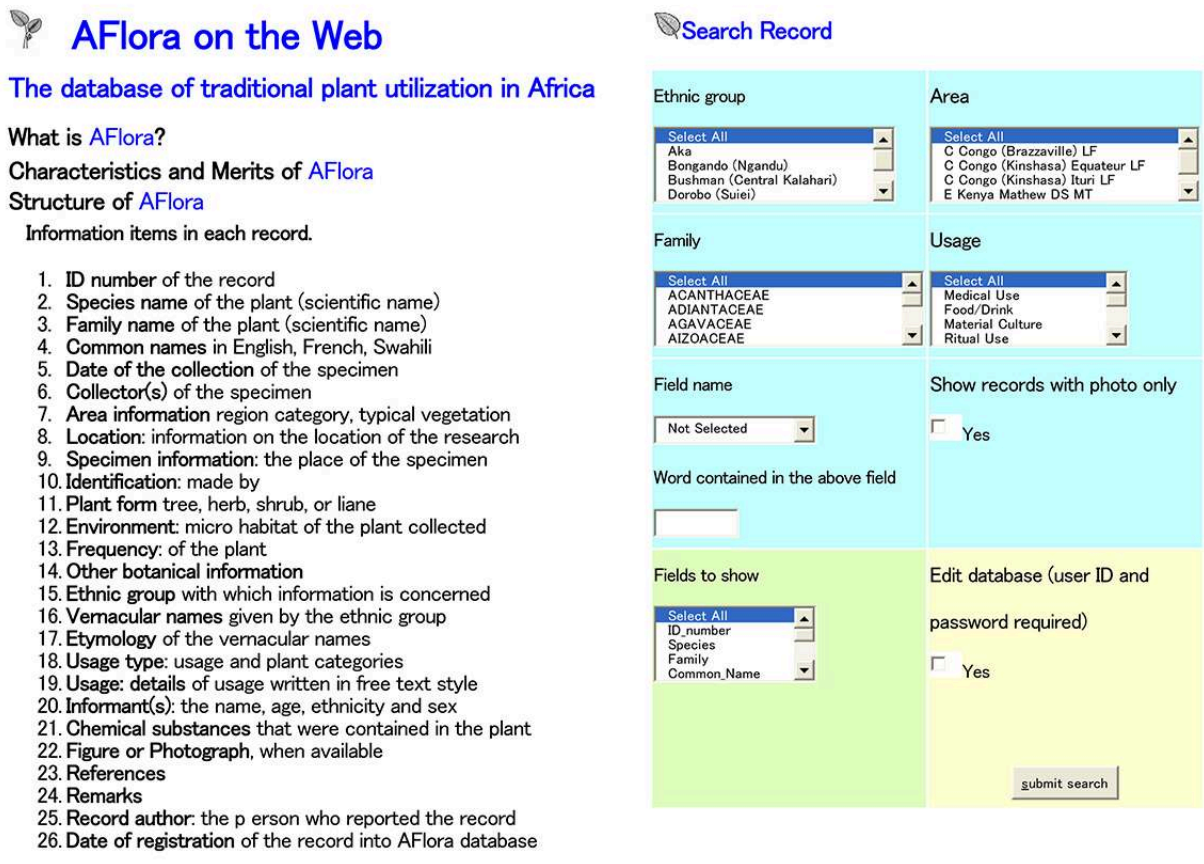

The database is currently closed to the public

\section{Variations in the people's knowledge}

While the central African forest people have surprisingly rich knowledge of plants, their knowledge system is not uniformly shared among the people. There are differences in the knowledge among different groups living in the same forest environment. Differences are also found among different residential groups of the same ethnic groups, or even among individuals of the same residential group. Let me examine such inter- and intra-group variations in the people's knowledge.

During the research in the Ituri Forest, we noticed the differences in knowledge of plant uses among different groups belonging to different linguistic groups, or even among the groups of the same linguistic groups, with similar lifestyle and environmental backgrounds. This is known as inter-cultural or intra-cultural variation, which has become an important issue in anthropology, and ethnobotany, in particular. Ichikawa \& Terashima (1996) and Terashima \& Ichikawa (2003) made a comparative study of the vernacular names and uses of plants among four different groups of hunter-gatherers, two from Bantu-speaking Mbuti and two from Sudanic-speaking Efe, all inhabiting a similar natural environment of the Ituri Forest, eastern Congo. The study showed considerable differences between the groups, even between the groups of the same language group. The plant vernacular names are mostly shared within the 
same language groups, and knowledge of important food plants is shared relatively well among these groups. The knowledge of medicinal plants, however, shows considerable differences, with only 10-26 \% shared by any pair of the two groups, even between groups belonging to the same language group (Ichikawa \& Terashima 1996). The authors further discussed the social background for such differences and suggested that there exist no strong social forces toward unification or standardization of knowledge in their society. Compared to other societies, theirs is characterized by a lower degree of social integration and a lack of centralized authority, of systematic school-like education, and of any other social mechanism that would otherwise facilitate cultural integration (or homogenization) of the society.

Such differences in the knowledge of plants are also found on individual levels in the same residential group, as Hattori $(2007,2020)$ reported on the knowledge of the Baka hunter-gatherers in Cameroon. She collected about 600 plant species, each with detailed ethnobotanical information among the Baka. For 90 commonly found species, she compared the knowledge possessed by 10 adult Baka informants belonging to different sex and age categories and found considerable differences in their knowledge. In particular, the knowledge of medicinal and ritual plants showed the greatest variation. Of the plants used for these purposes, less than one-fifth (20\%) were known to be used by six or more of the 10 informants. The knowledge of plants used for food and material culture was more commonly shared, with more than three-quarters of food plants used by all the 10 informants (Hattori 2007). These results show a similar tendency to the above-mentioned intergroup differences in the Ituri Forest case. Like the results from the intergroup comparison in the Ituri case, higher inter-individual similarity in food and material culture seems explicable: there are commonly acknowledged material bases for the plants used for food and material culture, such as nutritional value often represented by taste and smell, and hardness of wood or ease of work of the materials. As to the factors affecting the greater degree of difference for the medicinal plants, Hattori (2007) argued that this is due to the process by which such knowledge is transmitted. More than $80 \%$ of the knowledge of individuals was acquired from their parents, and most of the remaining knowledge from elder siblings, grandparents, and other elders. Typically, individuals learn about the medicinal plants when they are treated with these plants by their parents or other elders, or when they witness treatments done by their close relatives. As a result, the knowledge of medicinal plants is more or less of a personal nature, reflecting the life history of a person. In addition, the differences in medicinal and ritual uses of plants are maintained or even reinforced by their culture, which is characterized by a highly individualistic attitude toward knowledge of other people. They often let other people do things in their own ways, saying that "each person has his or her own medicine," effective for his or her cases of diseases (Hattori 2007).

The knowledge of medicinal and ritual plants is generally transmitted vertically within small family groups. In contrast, knowledge of plants used for food and material culture is transmitted not only vertically within families, but also horizontally, in particular, among children's play groups when they go out to the forest for foraging activities together. Moreover, the above-mentioned material bases of the plants facilitate such a horizontal transmission process. 


\section{Potential of the forest for hunter-gatherer subsistence}

19 Another finding from the study of cultural ecology is the potential of central African forest for hunter-gatherers' subsistence. Central African hunter-gatherers had long been thought to be the original inhabitants of the forest who had lived there long before the arrival of Bantu-speaking cultivators in the region. A question was raised in the late 1980s, however, against this idea of indigenous forest hunter-gatherers. The question was based on; 1) there is virtually no hunter-gatherer group today that depends solely on wild food resources without cultivated food obtained either from their own fields or from neighboring agricultural people, 2) no archaeological remains of hunter-gatherers had been found in tropical rainforests (but see Mercader et al. [2000], Mercader \& Brooks 2001, Mercader 2002), and 3) there is not enough wild food in the forest to sustain a self-sufficient hunting-and-gathering lifestyle, particularly in the dry season when little fruit, honey, or other food is available.

For this last reason, the question is often called the "wild yam question" because wild yams constitute a key food resource in humid tropical forests (Bailey et al. 1989, Bailey \& Headland 1991, Headland 1987, 1997). Such arguments were apparently influenced by the "revisionism" developed through the historical studies on the Kalahari huntergatherer societies by Wilmsen $(1986,1989)$ and others. The "indigenous" isolated life of the central African forest hunter-gatherers was also called into question.

Concerning the food resource base in the central African forests, several studies were conducted, mainly on the availability of wild yams (Hladik et al. 1984, Bahuchet et al. 1991, Hladik \& Dounias 1993, Dounias 1993). Sato (2001) also examined the potential of wild yams, and the possibility of a hunting and gathering life through the experimental survey of foraging life of the Baka people in Cameroon (Sato et al. 2014). There was, however, no empirical study based on the actual foraging life the Baka in the area.

We have been carrying out the research on the Baka hunter-gatherers since the middle of the1990s, when the political unrest in DRC became accelerated. Hirokasu Yasuoka, who joined the research in 2001, accompanied a Baka group of 50-60 people over the entire course of their hunting and gathering expedition, called molongo, which took place in the dry season. Based on quantitative data on their subsistence over this period, he demonstrated that a life dependent only on wild food (obtained from hunting and gathering in the forest) was possible, even in the dry season, a time generally regarded as being poor in food sources. They took as much as 2400 to 2800 kcal of food per person per day on average, which consisted of the meat of over twenty kinds of mammals and reptiles, ten kinds of plants, river fish, honey and edible insects. The most important sources of calorific intake were the wild yams, as the "wild yam question" had suggested ${ }^{2}$. In particular, the two species of yams with annual stems, Dioscorea praehensilis (called safa) and D. semperflorens (called esuma), accounted for three-quarters of the total food intake during this period (Yasuoka 2006a).

In a follow-up survey, Yasuoka (2009a, 2009b) investigated distribution of the wild yam, and based on that study, he made a very interesting point in terms of the history of the forest. He showed that the two yam species with annual stems were found in gaps, the forests with open canopy, called bi by the Baka, in contrast to yam species with perennial stems, which were mainly found in darker, closed forests (manja). In other words, the key food species that sustain molongo life are distributed in forests with sufficient light. 

food plants are light-demanding trees that require sufficient sunlight for germination and growth (Ichikawa 1996, 2001, see also Hart \& Hart [1986]). Antrocaryon and Ricinodendron, for example, are such sun trees. While they are often found today as big canopy trees in the dense forest, they must have germinated and grown in places where there was sufficient light. The sweet and sour fruit-bearing lianas of Landolphia species often grow in disturbed areas or on forest fringes. As mentioned above, Dioscorea spp. with annual stems also require sufficient light for accumulating starch in the tubers. While a big tree of Canarium schweinfurthii, also a light-demanding species, which produces delicious olive-shaped fruit, is now found in the remote forest, such a place was once inhabited by humans, either as a village or as a camp site. These plants 
must have grown from the discarded parts (tubers or seeds) left in the gaps where sufficient light reached to the ground.

In the forest, there are scattered gaps made by storms, lightning and other natural causes. While walking in the forest after a storm in the rainy season, we often found such newly formed gaps. In addition to these natural gaps, there are also traces of human activities in the forest. The hunter-gatherers sometimes cut down a tree with an ax for collecting honey, when they find it difficult to climb the tree to reach a beehive. In this case, a gap similar to natural ones is made artificially. When the huntergatherers open a new camp, they clear the underbrush and small to medium-sized trees, which allows sunlight to reach the ground. When the camp is abandoned, herbaceous plants of Zingiberaceae and Marantaceae grow quickly, followed by lightdemanding, fast-growing trees. The campsites will soon be covered with secondary vegetation similar to that regenerated from natural gaps.

Also found in the old campsites are seedlings germinated from the discarded food parts, such as the seedlings of Landolphia spp., Treculia, Ricinodendron and other food species. Moreover, large quantities of mineral nutrients and organic matter are concentrated in the campsite soils, resulting from the remains of food, fuels and other resources that are collected from a wide range of the forest and consumed at the camp.

31 I once estimated that a hunter-gatherer household of 5 persons uses 10 to $15 \mathrm{~kg}$ of firewood a day. The firewood consumed by 10 households, or 50 people, which is the average size of an Mbuti camp, during a month-long period, thus amounts to 3 to 4.5 tons, and the ashes from the firewood are deposited around the campsite. Food residues also contribute to the accumulation of mineral nutrients and organic matter in campsite soils. While not all of these materials remain in the soil, the nitrogen supplied from food and deposited as human excrements, alone is estimated to be equivalent to $200 \mathrm{~kg}$ of ammonium sulfate (Ichikawa 2001).

The materials in the soil are thus circulating in the forest, absorbed by the plants from the soil, then returned to the soil through consumption of the plants by animals. Human activities and habitation have also been playing a role in this circulating process. Their activities and habitation have contributed to concentrating these otherwise thinly distributed materials in localized patches, that is, in campsites. The campsites and the surrounding areas may provide a favorable place for the reproduction of food resources, though we need more data to verify this impression.

In the Ituri Forest, such forest campsites are situated at intervals of 3 to $6 \mathrm{~km}$ in a hunting-gathering territory, which ranges from 150 to $250 \mathrm{~km}^{2}$ (Ichikawa 1978). The Mbuti hunter-gatherers move from one camp to another every two weeks to two months in the hunting season (Ichikawa 1978). Sometimes a new camp is established in the forest and old ones are abandoned. I recorded in one of their territories as many as 30 such abandoned old campsites, which had become secondary forest at the time of the research. In these ways, the Mbuti often have positive impacts on the availability of food resources. Such extensive impacts of hunter-gatherers' activities and habitation on the surrounding vegetation and food availability call into question the clear-cut dichotomy of hunting and gathering versus cultivation.

However, hunter-gatherer habitation and subsistence activities have imposed only a limited impact. The villagers' settlements and agricultural activities have stronger impacts on the forest vegetation, because, in slash-and-burn agriculture, the original 
vegetation is largely removed from the fields. In the central part of the Ituri forest, DRC, the villagers' settlements are distributed today along the major roads penetrating the forest from north to south, and west to east. However, before the 1930's when these roads were constructed, there had been scattered small villages of shifting cultivators throughout the forest. Some of these former village sites can still be located in the satellite images as old secondary forest (Ichikawa 2001). Moreover, before the colonial period, villages more frequently shifted their location. Even in the colonial period, villages were often relocated owing to the re-arrangements of administrative zones and changes in the major routes of communication (Ichikawa 2001). All these movements and activities had extensive impacts on the forest vegetation.

On the ground level, these old secondary forests can be distinguished from mature forest by tree composition. The mature forest of Ituri is dominated by evergreen high trees of Caesalpinioid legumes, such as Cynometra, Julbernardia and Gilbertiodendron. The secondary forests, by contrast, are composed of a mixture of trees belonging to Euphorbiaceae, Moraceae, Meliaceae, Ulmaceae, and Malvaceae, some of which are deciduous trees. In some areas, there remain oil palm groves that were planted by former inhabitants or grew by themselves from the discarded fruit. It is noteworthy that there are twice as many major food tree and liana individuals in the secondary forest as in the primary forest; the former contained 13 individuals/ha on the average, compared with only six in the latter, according to American ecologists Terese and John Hart (1986).

All these observations suggest that we have to look more carefully into the history of human-nature interactions in the forest, particularly the ecological influences of past human habitation and subsistence activities on the forest environment.

The Baka in Cameroon today cultivate small crop fields (Kitanishi 2003, Yasuoka 2012), but they often move into the forest for foraging, leaving the unharvested crops in the fields. Cultivation for them is not entirely different from foraging. It is better to understand their simple cultivation as an extension and continuum of human intervention in the resource regeneration process, from partial vegetation modification, soil enrichment, seed dispersal and replanting parts of tubers, all of which eventually facilitate the growth and regeneration of resources, though these interventions do not always take place intentionally.

In our recent international cooperative project in Cameroon (described in more detail below), we investigated the distribution and abundance of the major wild food species in the forest of southeastern Cameroon. Hirai (2014) surveyed a total of about 4,000 plots in current and abandoned fields, and the vegetation of these plots around the village of Gribé, inhabited mainly by Kounabembe (Bantu-speaking) cultivators and Baka hunter-gatherers. In the season of 2012, a total of 47 hectares, comprised of 450 plots, were cleared for cultivation. In the cleared fields, a total of 3142 tree individuals (belonging to 240 species) with $10 \mathrm{~cm}$ DBH and over were left uncut, i.e., 66-67 individuals per ha of cleared fields. The villagers were asked about the reasons for leaving these trees ${ }^{3}$. Some said these trees provide shade to protect the fields from intense sunshine, especially in the fields of cacao, which need shade trees. Others said these trees are too hard to cut with small axes they usually use to cut down the trees. The wood of Irvingia gabonensis, in particular, is extremely hard, and trees of this species are often left uncut in the crop fields. Irvingia gabonensis produces a quantity of oily nuts, which are used for cooking, and is an important source of cash income 
(Ichikawa 2020, Toda \& Yasuoka 2020, Hirai \& Yasuoka 2020). Therefore, they are left in the fields also for an economic reason. Another food tree species often found in the fields is Ricinodendron heudelotti (called gobo by the Baka), which also produce edible nuts (used for making "sauce jaune," yellow-colored sauce) for sale. They were probably left deliberately because their wood is not hard but easy to cut down. These facts suggest that there may be relatively more useful (with edible fruit) tree species in the abandoned fields than in the uncut forest.

Fongzossie et al. (2014), Cameroonian counterparts of this project, compared the distributions of eight major wild food species in the forest, and found that some were more abundant in the secondary forests in the agricultural zones (non-permanent forest zone reserved for cultivation, usually the forest in a strip several kilometers in width along the road) than in the production forest (in the permanent forest zone) used for logging. Afrostyrax trees (the fruit and bark are used as a condiment for seasoning stews), for example, were found at densities of 52.4 individuals per hectare in the secondary forest, but only 10.8 in the permanent forest zone. Pentacletha (with edible nuts used when other food fails) were likewise more abundant in the secondary forests than in the permanent forests (16.6 individuals/ha vs 6.3 individuals/ha). The results seem explicable, because these trees are sun-loving trees that require sufficient light for germination and growth. Ngansop et al. (2019), also members of the project, confirmed these results, pointing out that seven out of eight major food species are more frequently found in relatively new secondary forests than in mature forests.

We should not forget, however, the diversity and variability of the tropical forests in central Africa. The variability is exemplified, for example, by the distribution of Afrostyrax mentioned above. The density of this species in a particular area shows almost ten-fold differences among different research sites (Hirai 2014, 2015, Tajeukem et al. 2014, Fongzossie et al. 2014, Ichikawa 2020). Irvingia gabonensis trees may also be unevenly distributed in the forest. It is not clear whether such uneven distributions are naturally caused or result through some human interventions. Hirai is now investigating this issue in the forests of southeastern Cameroon.

\section{Political Ecology: Commercialization and Local Exchange System}

\section{Stable exchange in an unstable national economy: the Mbuti case}

41 The peoples and forests in central Africa are no longer isolated from other parts of the world. Even the people in the remotest part of the forest have today more or less contact with economic and political systems of a wider society, on national as well as international levels. The forest destruction in Africa and nature conservation movements against it are in themselves closely linked to the global dynamics of economy, politics and information. If we imagine an area where humans and nature coexist independently from such a larger society, it would be like a "living museum of humans," an image strongly opposed by development planners, local governments and by hunter-gatherers themselves. Living people and their society are changing through interactions between internal dynamics and external relationships. became known as such in the late $19^{\text {th }}$ and early $20^{\text {th }}$ centuries through increasing 
demand for ivory in the Western world (Sommerville 2014, Ichikawa 2021). Since the $19^{\text {th }}$ century, ivory had been one of the major export items (Nelson 1994). The ivory, together with wild rubber (also called "red rubber" for the bloody nature of its exploitation), accounted for $85 \%$ of exports (in monetary value) from the Congo Free State and the Belgian Congo (Jewsiewicki 1983). In the Ituri forest, the Mbuti also provided the tusks of elephants until recently.

More recently, net hunting among the Mbuti in southeastern parts of the Ituri forest was intensified by the changing economic conditions of the region, such as the growth of local towns in the region that demanded quantities of bushmeat, or the rush for gold dust, both of which accelerated the bushmeat trade for providing people with a protein source. People in towns also value bushmeat as a source of "wild power" that cannot be obtained from domestic animals (Ichikawa et al. 2016).

The sedentarization of the forest hunter-gatherers along the major roads, and their subordinate relationship with neighboring farmers, were probably linked to the increasing demand for their labor force for promoting the production of cash crops, which in turn was influenced by the world capitalist economy that seeks a cheap labor force and primary products in African rural areas. This was probably the case in the southeastern part of Cameroon, where the introduction of cacao growing and sedentarization of the Baka hunter-gatherers were taking place almost simultaneously in the late 1950s to early 1960s (Althabe 1965). In addition, in order to have access to industrial goods, medical care, school education and other modern services, the Baka themselves needed contact with outside economy and to exchange their labor and forest products for these goods and services. International movements toward forest conservation will inevitably influence their relationships with the forest and with their agricultural neighbors.

It is therefore necessary to examine the relationships of the forest hunter-gatherers' life and culture with the political and economic situations of a wider society. There are various problems in these relationships, particularly in the current political and economic crises that African countries are facing. One of our tasks was to show how the forest people can cope with these problems; that is, how they can establish their relative autonomy faced with the prevailing external influences. I will show a suggestive example that I witnessed in DRC in the 1970s and 1980s; that is, the example of bushmeat trading (see Ichikawa 1991 and 2000 for more details of this example).

Hunting for bushmeat in recent decades became a hot issue in conservation (Wilkie \& Carpenter 1999), because it may deplete the faunal resources in the forest, resulting in the so-called "empty forest syndrome" (Redford 1992). In central Africa, excessive hunting and trade for meat were accelerated by the economic changes in rural and urban areas, which resulted partly from the economic crisis and structural adjustment programs in the late 1980s (Ichikawa 2006). In most parts of central Africa, the bushmeat trade was increasing remarkably in the 1980s and $1990 \mathrm{~s}^{4}$.

The bushmeat trade in the Ituri forest in the 1970s and early 1980s was, however, not carried out to such a destructive extent (see, Ichikawa [1996]). This is probably because of the stable local exchange system that served as a "buffer" to protect the local exchange system from the disruptive effects of outside economy, and eventually maintained the hunting pressure at a moderate level. Let me explain this briefly.

The national economy of DRC (former Zaire) had been worsening year by year since the country's independence. In spite of devaluation and sudden change of high-value 
banknotes, the prices of commodities rose 60-fold during the 15 years since independence, whereas the real wage dropped to one-quarter of its initial value during the same period (Young \& Turner 1985). The national economy further deteriorated in the 1980s, with the annual inflation rate reaching as high as 100 per cent (the annual inflation rate rose to $1000 \%$ or more in the 1990s, and the former Zairian economy finally fell into a state of hyperinflation). Under such conditions, townspeople, wage laborers in particular, could hardly survive, if they had to depend solely on the cash economy of the formal sector.

In the Ituri forest where the Mbuti people live, the prices of commodities also rose by several hundred to a thousand times during the 12 years from 1975 to 1987 and continued to rise in the 1990s. A considerable change mostly disadvantageous to the Mbuti $^{5}$, also occurred in the relative cash price of meat or labor force to other commodities (Figure 3). The Mbuti, however, rarely receive cash for their labor and meat, except when they need cash for some specific purposes, such as for paying tax, fine or bride wealth, or for alcoholic drinks. When they provide the farmers with day labor (called par jour), they receive three cassava plants with about $15 \mathrm{~kg}$ of tubers. This amount remained constant throughout the research period, though the relative cash price of cassava to wage labor rose more than a double during the same period. Likewise, they usually barter bushmeat for agricultural food and other commodities. One unit of meat (equivalent to about $2 \mathrm{~kg}$ ) was exchanged for ten glasses (or six small bowls) of cassava flour (about $2000 \mathrm{~g}$ ), and this exchange rate remained fairly stable during the research period, in spite of the changes in the relative cash prices of meat and cassava flour (Ichikawa 1991, 2000).

Figure 3 : Change in the relative cash prices between goods and wage in the Teturi region, Ituri Forest

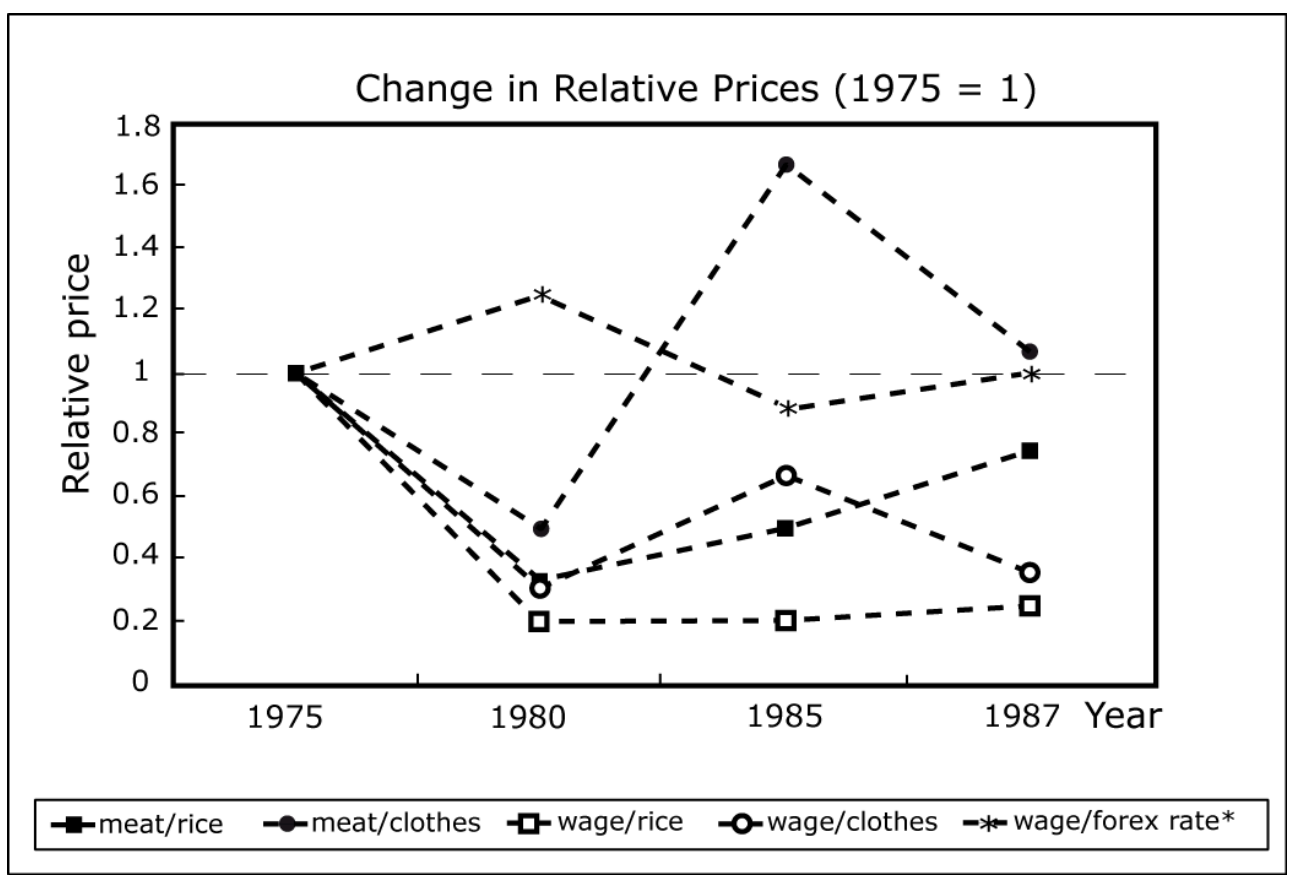

* actual zaire/US\$ exchange rate

For the Mbuti, the most important thing is the amount of agricultural food obtained from the exchange, no matter how the cash prices of meat and agricultural food may 
change. It is the food, clothes or other consumer goods that they want to acquire from the exchange. Such a stable exchange aiming at acquiring concrete use values has served as a buffer against the extremely unstable national economy of former Zaire.

If there had been no such buffer, they would have been forced, for example, to hunt more animals when the relative cash price of meat decreased. Moreover, they might have pursued maximization of hunting yields, which would have resulted in higher hunting pressure on the forest animals. We should therefore acknowledge the implications of such a stable exchange system for maintaining the local resource base and the forest people's life in the unstable national economy. We do not know if such a type of exchange could be maintained for a long time under the prevailing influences of cash economy and consumerism. Nor would I suggest that this will remain a desirable form of exchange in the future. I would rather suggest that such a barter style exchange has contributed to maintaining a stable life, or "human security," in the difficult economic situation in the region. If market economy imposes increasing impacts on the forest people's life, it is necessary to secure their rights over the forest resources, which would eventually enable them to manage forest resources from a longer-term perspective and utilize them on a sustainable basis.

\section{Forest conservation and commercialization of NTFPs: The Baka case}

There are two important issues raised recently that influence the relationships between man and nature in central Africa. These issues are raised by the Stern Review (Stern 2006), a report from the British Government on global warming and its impacts, and by the UN declaration on the rights of indigenous peoples (United Nations 2007). How to cope with these two issues in an integrated manner is crucial to the people whose culture and life are heavily dependent on the natural environment (Ichikawa 2014).

Protection of the natural environment and economic development have been thought to be in a trade-off relationship, in that the pursuit of the former would undermine the latter. According to the Stern Review, however, it would be economically better at the global level to protect the environment. The economic loss in global GDP from global warming would be $5 \%$ each year (it could be as high as $20 \%$ ), whereas the cost of mitigation of global warming would be $1 \%$ (Stern 2006). The reduction of greenhouse gases is, therefore, necessary and economically viable.

The UN declaration on the Rights of Indigenous Peoples, adopted in 2007, stipulates that indigenous peoples have the rights to "...freely pursue their economic, social and cultural development (Art.3)" and "...maintain and strengthen their distinct political, legal, economic, social and cultural institutions... (Art. 5)." This declaration clearly supports the indigenous movements toward pursuing economic development while retaining their culture.

How can hunter-gatherers pursue economic development while retaining their unique culture and preserving the forest environment? We think the use of non-timber forest products (NTFPs) will be the key to integrating these seemingly contradictory goals. NTFPs are produced by living trees, unlike the timber which is the final and dead product of trees, and in this sense exploitation of NTFPs would be compatible with forest conservation. As the people have long been using the NTFPs for maintaining 
their livelihood, the use of NTFPs is culturally appropriate and contributes to the household economy, if the products are commercialized in a proper, sustainable way.

People living in the southeastern region of Cameroon have been facing difficulties. Their forests have been destroyed by industrial logging since the 1980s, and they are also excluded from protected areas that in the past were a source of sustenance. Moreover, a large part of production forests (logging zone) was allocated to sport hunting for wealthy people from Western countries. As a result, nearly $90 \%$ of the forest area has been allocated to external stakeholders, and local people are excluded from the forests they had been utilizing for centuries (Figure 4). Activities of the Baka in these areas are either totally or severely restricted. This is a typical scenario of land grabbing or green grabbing (Fairhead et al. 2013), and a similar scenario is encountered in various parts of the tropical rainforests in central Africa where people inhabit land with rich biological diversity. Establishing a sustainable system of land and resource utilization is now an urgent problem for these people, in particular, the Baka people who heavily depend on the forest resources. We embarked, therefore, on a project for establishing a sustainable use of NTFPs in the southeastern region of Cameroon.

Figure 4 : Zoning of project area, southeastern Cameroon

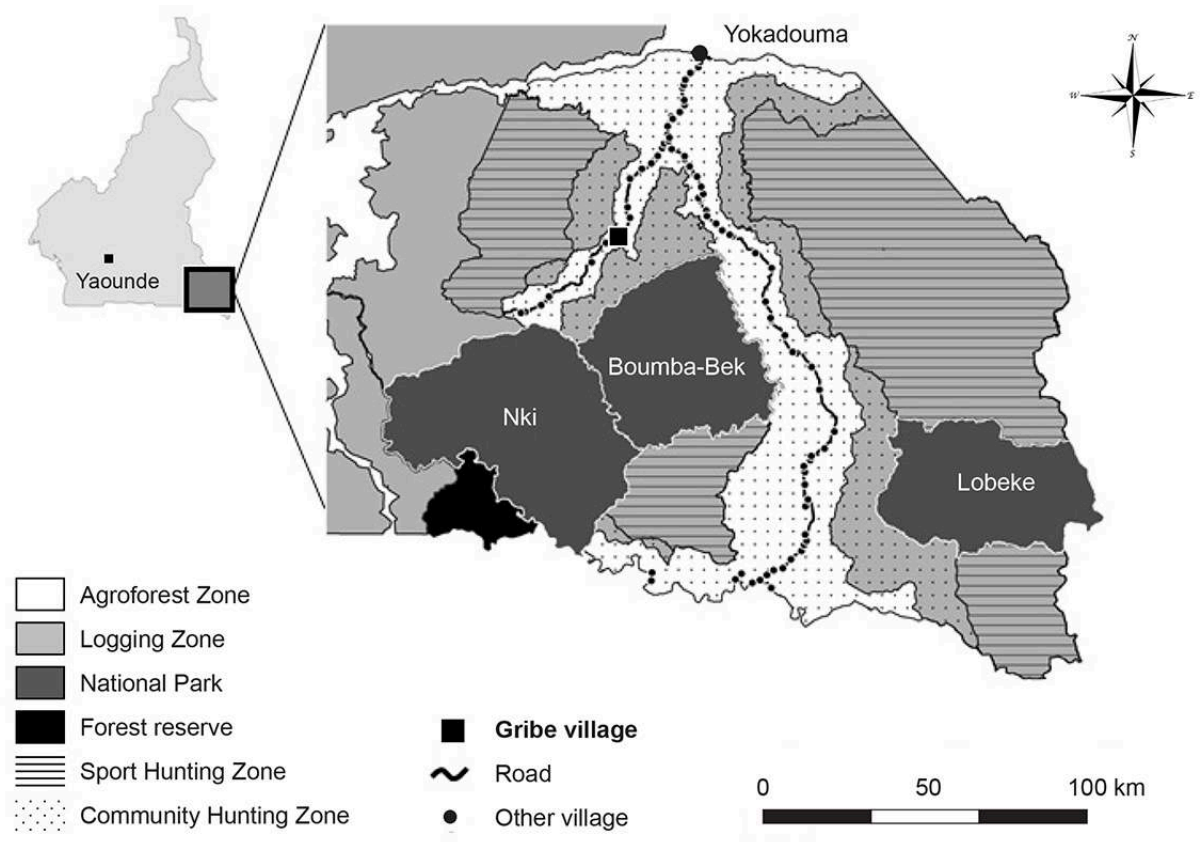

The community hunting zone in the logging zone (dotted area with grey color) to the southeast of Gribe is now leased to sport hunting company

Adapted and modified from Hirai (2014) and Ichikawa (2020)

The project was carried out in cooperation with the Cameroonian counterpart (IRAD = Institut camerounais de Recherche Agricole pour le Développement), and sponsored by JICA (Japan International Cooperation Agency). A field research station was built in Gribé, a village in southeastern Cameroon comprising approximately 400 Baka huntergatherers and a similar number of Bantu-speaking (Kounabembe) agricultural peoples (Toda 2014). A newly constructed road connects Gribé to Ngato in the east and Lomie in the west. Gribé is adjacent to Boumba-Bek and Nki National Parks on the southern and 
western sides, with UFA (Unités Forestières d'Aménagement, or Forest Management Unit) on both sides of the village (Figure 4, see also Ichikawa [2020]).

Figure 5 : Research station at Gribé, southeastern Cameroon

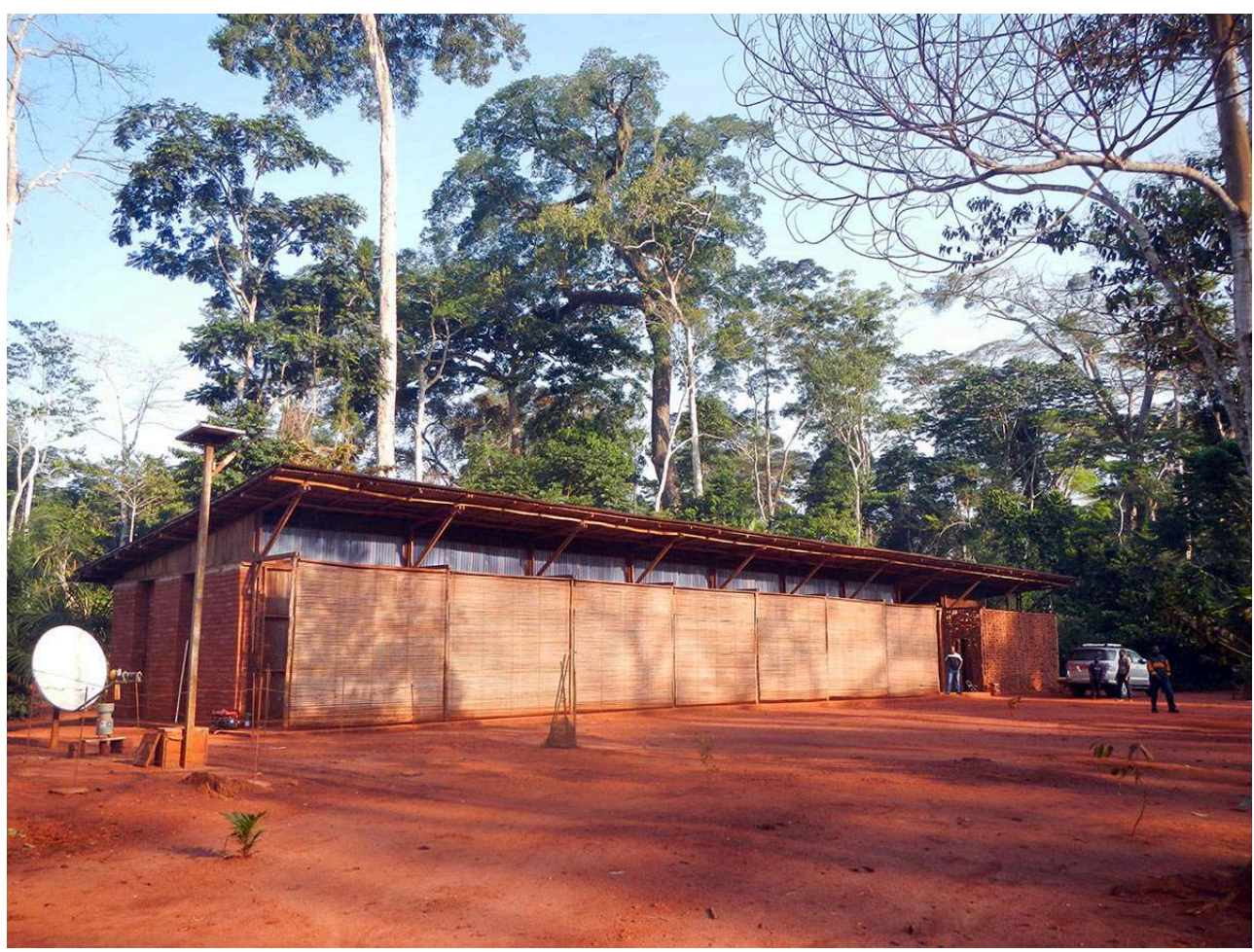

(c) M Ichikawa

The research consisted of three parts: (1) the ecological potential of NTFPs (their abundance, productivity, and availability in the forest), (2) actual use of NTFPs and their contribution to people's subsistence and household incomes, and sustainability of NTFP uses by comparing them the results from part (1), and (3) local practices and customs of forest use for avoiding excessive competition over the resource and designing sustainable resource management strategies (Ichikawa 2020). Let me introduce some of the findings from this project, focusing on the use of Irvingia gabonensis nuts (called peke in Baka language), one of the most important NTFP species in the region.

59 As to the ecological potential of Irvingia nuts, Hirai and Yasuoka (2020) estimated the average annual production of nuts at 6-7 kg (dry weight)/ha, reaching $14 \mathrm{~kg}$ in good years. This means a total of 210-220 tons of dry nuts produced in an area of $360 \mathrm{~km}^{2}$, which they have been customarily using for their livelihood. While the production of the nuts fluctuates considerably from year to year, they usually collected only 5-6 \% of the total production (Hirai \& Yasuoka 2020). The resource base of Irvingia nuts is, therefore, super-abundant.

There are, however, constraints on the use of this abundant resource. One is the timeconsuming work of splitting the fruit with machetes, and removing the kernels from the stony endocarp. It usually takes 5-6 hours to get 2-3 kg (dry weight) of nuts. More efficient tools could improve the efficiency of this work. Another constraint is restricted access to the gathering ground (Hirai \& Yasuoka 2020). As mentioned above, 
$90 \%$ of the area they have been customarily using has been designated as protected area (Boumba-Bek National Park), to which access by local people is restricted. Moreover, a large part of the logging areas surrounding the parks has been allocated to ZIC (Zone d'Intérêt Cynégétique) for sport hunting by wealthy foreigners. While gathering activities in this zone are not legally prohibited, the operator of sport hunting opposes the entry of the local people into their ZIC out of fear that the people might also set animal traps in the forest while gathering the nuts (Hirai \& Yasuoka 2020). In these ways, the forest policy and zoning of the Cameroon state is endangering the basis of Baka subsistence and cash income.

61 There is also a problem in the transaction of the Irvingia nuts. Most of the nuts in the area are collected by the Baka. They collect the fallen fruit in the forest where there are abundant Irvingia trees and remove the kernels on the spot. After several hours of monotonous work, they return to the forest camp with a few kilograms of nuts wrapped with Marantaceae leaves. The nuts are exchanged for food or alcoholic drinks with the Bantu villagers (mostly Kounabembe people) waiting at the camp. They are also used to repay the credit for agricultural food or alcoholic drinks the Baka have received in advance in the village (Toda \& Yasuoka 2020).

The nuts are usually exchanged at a fixed rate, one combo (nuts filling a 2_litre enamel bowl, weighing 1.4-1.5 kg dry weight) for 10 beignets or 5 sachets of whisky, equivalent to $500 \mathrm{CFA}$ (the actual rate becomes somewhat higher, because of the unpaid advance borrowings by the Baka). The Bantu villagers dry the nuts, either with fire or sun (for better quality) and transport them to the village where traders from both within and outside the village are waiting. The price of the dried nuts in the village is 1500 to 2500 $\mathrm{CFA} /$ combo, although it fluctuates depending on the availability of the nuts and on the number of competing traders in the village. The traders then transport the nuts in large bags to towns, sometimes as far as Nigeria. A part of the nuts is also sold at a market in Yokadouma (prefectural center), where the retail price is $100 \mathrm{CFA}$ for $40 \mathrm{~g}$ of dried nuts, or 3500 to 4000 CFA for a combo (Hirai \& Ichikawa 2018). The price of the nuts in Yokadouma, therefore, rose to 7-8 times higher than that in the forest camp.

While most of the nuts collected in the forest are exchanged with the Bantu people in the forest camp, some of the Baka sell the nuts for cash to the traders in the village. The amount sold by the Baka is, however, much smaller than that of the Bantu villagers. In the 2012 season, the total amount of nuts sold by the Baka to the traders in Gribe was about 190000 CFA in total, about one-tenth of that sold by the Kounabembe villagers ( 1830000 CFA). The average individual sale by the Baka to the traders in the same year was about 7000 CFA, whereas the Kounabembe villagers sold more than 120000 CFA per individual seller (Hirai \& Ichikawa 2018).

64 Amount sold by the Baka per transaction (sale) was also much smaller. In most cases, Baka sold only 1-2 combo, and spent the money immediately on food, kerosene for lamps, alcoholic drinks, and other consumer goods. Money has general purchasing power and can be kept for future use or to buy some expensive goods. It can also be used for their children's school fees, or for medical care, when necessary. It can even be used for "investments," such as hiring manpower to expand their crop fields, and other profit-making activities. However, they are not accustomed to store money for purposes that are not among their immediate needs. Their consuming behavior is characterized by their "interest in the present." 

rcialized, nor exchanged with the people from the outside world, they are used in a diversity of ways, and have important meanings to the hunter-gatherers' life and culture. We should appreciate, therefore, the use values of these plants and animals. The culture of the forest hunter-gatherers is dependent on and inseparable from the diversity of forest plants and animals. It is essentially different from the market economy, which demands only a few resources with high market value, such as timber, ivory, bushmeat, etc. The commercialization of forest resources might therefore distort 
the hunter-gatherers' rich forest-based culture, which can be seen as a criticism of our too practical and commercially-oriented use of the forest.

While central African hunter-gatherers depend heavily on forest resources, they may have contributed to regeneration of the resources through their habitation and subsistence activities in the forest. Through frequent shifts of campsites and livelihood activities, places with open vegetation and nutrient-rich soils are formed, which favor the reproduction of edible plants. The mineral nutrients and organic matter in the resources are circulating in the forest system, returning to the forest through human consumption, if the resources are not carried out of the forest. The forest world can thus be depicted as a system in which people and the forest are coexisting, interdependent on each other.

71 We have presented a few examples to show that the forest environment of southeastern Cameroon as a human habitat has been improved by human activities. If these findings on the positive impacts are confirmed in different areas or in wider areas, we can confirm that the forest people not only depend on the forest resources, but also have contributed to maintaining, or even improving, the resource base for their subsistence. Then, the current scheme of forest protection based on the opposition between human and nature should be reconsidered. The current model of establishing "wildlife sanctuaries" from which human activities are excluded may be replaced by a model of coexistence between humans and the forest.

Various studies suggest that the availability of plant food is improved by intentional and/or unintentional human impacts on vegetation. Australian hunter-gatherers and Native Americans are known to fire the land to facilitate the growth of specific edible plants. In California, the land has been managed through burning, tilling, weeding, and various other ways by native Amerindians for more than 10000 years, which has influenced the abundance and composition of the flora and fauna in the region (Anderson 2005). Around some Jomon prehistoric sites in Japan, archaeologists pointed out the patches of concentrated chestnut trees, which had presumably formed as byproducts of sedentarization (Nishida 1997). Such positive impacts of human activities and habitation on the surrounding vegetation and food availability call into question the clear-cut dichotomy of hunting-and-gathering versus cultivation.

The forest patches distributed on the savanna-forest borders in northern Guinea, a west African country, are good examples of positive intervention on the environment by people. These forest patches, known as "forest islands" by researchers and administrators, were believed to be the relics of forest vegetation that had once covered the entire region, but had been destroyed by cultivators who preferred savanna to forest. British anthropologists Fairhead \& Leach (1996) showed, however, based on old aerial photographs, satellite images, and historical materials as well as villagers' oral traditions, that these "forest islands" were historical products formed by human interventions.

74 Another example is the Marantaceae forest, a forest with thick undergrowth of Marantaceae herbs, in the west African wet zone. While this type of forest provides the African great apes (gorillas) with an important habitat (Wrangham 1986), the research indicated that a large part of this forest in west Africa was actually formed under human influences, in particular by fires associated with slash-and-burn agriculture (White 2001). It would be interesting to determine whether such an important habitat 
of the great apes might have been generated through human interventions, which are usually thought to be destructive to the forest environment.

Moreover, recent examination of human history in tropical rain forests in a global scale (Roberts 2019) revealed extensive human impacts on these forests, which had often been thought to have little human traces.

The traces of human activities in the Congo Basin were found in quite old time; some of the prehistoric sites date back to about 1000 years BC (Vansina 1990, see also Roberts [2019]). During research on the Aka hunter-gatherers and Bantu cultivators in the densely forested area of upper Motaba River in Congo-Brazaville, our colleagues found several charcoal layers in the soil, when they dug pits to examine the soils. The charcoals from the deepest layer were dated to 2,600 BP (Chujo 1993, Hanawa \& Komatsu 1993). These charcoals likely indicate the traces of early slash-and-burn agriculture. We were impressed by the evidence of agriculture in this area at such an old time.

An aerial view of the Congo forest gives us an impression that there still remains a vast stretch of intact forest. However, as Vansina (1990) and other historical studies suggested, the Bantu-speaking shifting cultivators had migrated into the heart of the Congo Basin by the end of the first millennium, and have lived there for more than a thousand years. Their population density was probably not high, but one thousand years of occupation may be long enough for them to have left their traces throughout the forest. As the ecologist Richards (1996) wrote, African forests that appear to be primary forest are actually often old secondary forests. Therefore, it is necessary to reconsider the local forest environment in the light of "environmental revisionism" (a term phrased by Headland [1997]), which sees the forest in a different way from conventional ecology, postulating historical human interventions in the forest vegetation.

78 The commercialization of NTFPs provides Baka hunter-gatherers with an opportunity for cash income and means to combine their welfare with forest conservation. However, this opportunity has not been enjoyed equally among the local peoples. The existing economic disparity between the Baka hunter-gatherers and Bantu (Kounabembe) farmers is increasing through this commercialization, because the latter control the circulation of the forest products. If the Baka were to transport the nuts to the village and sell them directly to the traders, they could get 3-4 times more money than by selling them in the forest. If they were to further transport the nuts to towns by themselves, they could gain 7-8 times more money. However, they have not been engaged much in such activities and are unlikely to do so anytime soon. This owes to the interethnic relationship between the Baka and the Bantu farmers. There has been a long-standing relationship between them, in which the Bantu villagers play an intermediary role between the Baka and the outside world and control commercial activities with the outside world.

The consequences of such a disadvantageous social position of the Baka are seen in various fields in their social life. There are increasing trends in Cameroon today toward decentralization and local participation in forest governance, and the issues on conservation and use of tropical rainforests are not an exception. The local people are granted the right to exploit the timber resources in the "community forest" in the "non-permanent forest zone", on the condition that their management plan is approved by the government. They can sell the wood to the logging company operating 
in the area. Moreover, the community hunting zone (ZICGC = Zone d'Intérêt Cynégétique à Gestion Communautaire) is also allocated to the local community, and it is leased to an overseas safari hunting (sport hunting) company to get the royalty. The committee members of the community forest and COVAREF (Comités de Valorisation des REssources Fauniques), responsible for negotiations with logging company or safari hunting agents, include representatives of the Baka people, reflecting the outside (international and national) pressure to involve the Baka people in local forest management. The representatives of the Baka are, however, arbitrarily selected by the Bantu leaders, and they have little voice on issues originating from the outside world, because the contact with outside world has been almost entirely monopolized by the Bantu villagers. Moreover, they themselves are not accustomed to such a "representative system," as their non-hierarchical, egalitarian social structure does not fit with such a system.

Now, the commercialization of NTFPs as a way to combine forest conservation with people's welfare is attracting increasing interest from the local people and government, and international development and conservation organizations. In order to spread the benefits of such new economic opportunities equally among local people, it is necessary to take appropriate measures based on a deep understanding of the local ethnic relationships and their historical background.

This study was supported in part by JSPS KAKENHI (Grant Number 20K12370). I wish to thank all the people who kindly accepted us and assisted our fieldwork, which has been conducted for nearly a half century since 1974. We extend our thanks in particular to the Mbuti and Efe people in Democratic Republic of Congo, the Aka people in the Republic of Congo, and the Baka people in Cameroon. I would like to thank Dr. Doyle Mckey for his valuable comments and advice.

\section{BIBLIOGRAPHY}

Aflora Committee 1987 - Introduction to Aflora: An on-line database for plant utilization of Africa, Afr. Stud. Monogr. 9(1): 55-64.

Althabe G. 1965 - Changements sociaux chez les Pygmées Baka de l'est Cameroun. Cahiers d'Etudes Africaines 5 (20): 561-592.

Anderson K.M. 2005 - Tending the Wild: Native American Knowledge and the Management of California's Natural Resources. Berkeley: University of California Press, 526p.

Bahuchet S., McKey D. \& Garine I. de 1991 - Wild yams revisited: Is independence from agriculture possible for rain forest hunter-gatherers? Human Ecology 19 (2) : 213-243.

Bailey R.C., Hea G., Jenike M., Owen B., Rechtman R. \& Zechenter E. 1989 - Hunting and gathering in tropical forest: Is it possible? American Anthropologist 91 (1) : 59-82.

Bailey R.C. \& Headland T.N. 1991 - The tropical rain forest: Is it a productive environment for human foragers? Human Ecology 19 (2) : 261-85.

Carrière S.M. 2002 - Orphan trees of the forest: Why do Ntumu farmers of Southern Cameroon protect trees in their swidden fields. Journal of Ethnobiology 22 (1) :133-162. 
Chujo H. 1993 - Ecological observation of the vegetation and soils in Djoube area of Northern Congo 1992. Rapport Annuel 1992-1993. Centre des Études Africaines, Université de Kyoto, 7-8.

Dounias E. 1993 - Perception and use of wild yams by the Baka hunter-gatherers in south Cameroon. In : Hladik C.M., Hladik A., Linares O.F., Pagezy H., Semple A. \& Hadley M. (Ed.), Tropical Forests, People and Food. Biocultural Interactions and Applications to Development. Paris, Parthenon : 621-632.

Dounias E. 2001 - The management of wild yam tubers by the Baka Pygmies in southern Cameroon. Afr. Stud. Monogr. SI $26: 135-156$.

Evans M.I. 1993 - Conservation by commercialization. In : Hladik C.M., Hladik A., Linares O.F., Pagezy H., Semple A. \& Hadley M. (Ed.), Tropical Forests, People and Food. Biocultural Interactions and Applications to Development. Paris, Parthenon : 815-822.

Fairhead J. \& Leach M. 1996 - Misreading the African Landscape. Cambridge University Press, 383 p.

Fairhead J., Leach M. \& Scoones I. 2013 - Green Grabbing: A New Appropriation of Nature? Routledge, $408 \mathrm{p}$.

Fongzossie F.E., Ngansop T.M., Zaphack L., Kemeuze V.A., Sonwa D.J., Nguenang G.M. \& Nkongmeneck B.A. 2014 - Density and Natural Regeneration Potential of Selected Non-Timber Forest Products in the Semi-deciduous Rainforest of Southeastern Cameroon. Afr. Stud. Monogr. SI $49: 69-90$.

Gallois S., van Andel T., Heger T., Sonke B. \& Henry A.G. 2020 - Comparing apples and pears: the hidden diversity of central African bush mangoes (Irvingiaceae), Economic Botany 74 (2) : 17-194.

Hanawa R. \& Komatsu K. 1993 - A brief account of the Bondongo in the Motaba river, Lokouala Region. Rapport Annuel 1992-1993. Centre des Etudes Africaines, Université de Kyoto, 9-12.

Harako R. 1976 - The Mbuti as hunters: A study of ecological anthropology of the Mbuti Pygmies. Kyoto Univ. Afr. Stud. 10 : 37-99.

Hart T. \& Hart J.A. 1986 - The ecological basis of hunter-gatherer subsistence in the Ituri Forest of Zaire. Human Ecology $14: 29-55$.

Hattori S. 2006 - Utilization of Marantaceae plants in southeastern Cameroon. Afr. Stud. Monogr. SI $33: 29-48$.

Hattori S. 2007 - Variability of plant knowledge concerning vernacular names of plants and their uses among adult Baka hunter-gatherers in Cameroonian rainforests. Jap. J. Afr. Stud. $71: 21-40$. (in Japanese).

Hattori S. 2020 - Diversity and similarity relating to plant knowledge among Baka huntergatherers in southeast Cameroon. Afr. Stud. Monogr. SI 60 : 39-57.

Headland T.N. 1987 - The wild yam question: How well could independent hunter-gatherers live in a tropical rain forest ecosystem? Human Ecology 15 (4) : 463-491.

Headland T.N. 1997 - Revisionism in ecological anthropology. Current Anthropology 38 (4) : 605-630.

Hirai M. 2014 - Agricultural land use, collection and sales of non-timber forest products in the agroforest zone in Southeastern Cameroon. Afr. Stud. Monogr. SI 49 : 169-202.

Hirai M. 2015 - Potentials, Livelihood and Social Relationship of Non-timber Forest Product Use : A Case of Irvingia gabonensis. Paper presented at FOSAS International Symposium. Yaounde, 11-12th November 2015. 
Hirai M. \& Ichikawa M. 2018 - Social Problems in the Commercialization of NTFPs in Southeastern Cameroon. Paper presented at International Conference of Ethnobiology, 7-10 Aug., Belem, Brazil.

Hirai M. \& Yasuoka H. 2020 - It's not the availability, but the accessibility that matters: ecological and economic potential of non-timber forest products in southeast Cameroon. Afr. Stud. Monogr. SI $60: 59-83$.

Hladik A., Bahuchet S., Ducatillion C. \& Hladik C.M. 1984 - Les plantes à tubercules de la forêt dense d'Afrique Centrale. Revue d'Ecologie (Terre et Vie) $39: 249-290$.

Hladik A. \& Dounias E. 1993 - Wild yams of the African forest as potential food resources. In : Hladik C.M., Hladik A., Linares O.F., Pagezy H., Semple A. \& Hadley M. (Ed.), Tropical Forests, People and Food. Biocultural Interactions and Applications to Development. Paris, Parthenon : 163-176.

Hongo S. Dzefack Z.C.B., Vernyuy L.N., Minami S., Nakashima Y., Djieto-Lorden C. \& Yasuoka H. 2020 - Use of multi-layer camera trapping to inventory mammals in rainforests in southeast Cameroon. Afr. Stud. Monogr. SI 60 : 21-37.

Ichikawa M. 1978 - The residential groups of the Mbuti Pygmies. Senri Ethnological Studies 1 : 131-181.

Ichikawa M. 1983 - An examination of hunting-dependent life of the Mbuti Pygmies, Eastern Zaire. Afr. Stud. Monogr. 4 : 55-76.

Ichikawa M. 1991 - The Impact of Commoditisation on the Mbuti of Zaire. Senri Ethnological Studies $30: 135-162$.

Ichikawa M. 1996 - The co-existence of man and nature in the African rain forest. In : Ellen R. \& Fukui K. (Ed.), Redefining Nature. Oxford, Berg Publishers : 467-492.

Ichikawa M. 2000 - Interest in the present in the nationwide monetary economy: The case of Mbuti hunters in Zaire. In : Schweitzer P., Biesele M. \& Hitchcock R.K. (Ed.), Hunters and Gatherers in the Modern World. Oxford, Berghahn : 263-274.

Ichikawa M. 2001 - The forest world as circulation system: the impact of Mbuti habitation and subsistence activities on the forest environment. Afr. Stud. Monogr. SI 26 : 157-168.

Ichikawa M. 2006 - Problems in the conservation of rainforests in Cameroon. Afr. Stud. Monogr. SI $33: 3-20$.

Ichikawa M. 2014 - Forest conservation and indigenous peoples in the Congo Basin: new trends toward reconciliation between global issues and local interest. In : Hewlett B.S. (Ed.), Hunrergatherers in the Congo Basin. Transaction. New Jersey, Transaction publishers : 321-342.

Ichikawa M. 2020 - Toward sustainable livelihood and use of non-timber forest products in southeastern Cameroon. Afr. Stud. Monogr. SI 60 : 5-20.

Ichikawa M. 2021 - Elephant hunting by the Mbuti hunter-gatherers in the Eastern Congo Basin. In : Konidaris G.E. Barkai R., Tourloukis V. \& Harvati K. (Ed.), Human-Elephant Interactions: from Past to Present. Tubingen, University of Tubingen Press : 455-467.

Ichikawa M. \& Terashima H. 1996 - Cultural diversity in the use of plants by the Mbuti Huntergatherers. In : Kent S. (Ed.), Cultural Diversity of the Twentieth Century Foragers. Cambridge, Cambridge University Press : 276-293.

Ichikawa M., Kimura D. \& Terashima H. 2001 - AFlora: A Database of Traditional Plant Use in Tropical Africa. Systematics and Geography of Plants 71 (2) : 759-764. 
Ichikawa M., Hattori S. \& Yasuoka H. 2016 - Bushmeat Crisis, Forestry Reforms and Contemporary Hunting Among Central African Forest Hunters. In : Reyes-García V. \& Pyhälä A. (Ed.), Hunter-gatherers in a Changing World. New York City, Springer : 59-75.

Jewsiewicki B. 1983 - Rural society and the Belgian colonial economy. In : Birmingham D. \& Martin S.M. (Ed.), History of Central Africa. London, Longman : 95-125.

Kamgaing T.O.W., Bobo K.S., Djekda D., Azobou K.V.B., Bobo R.H., Balangounde M.Y., Simo K.J. \& Yasuoka H. 2018 - Population density estimates of forest duikers Philantomba monticola \& Cephalophus spp.) differ greatly between survey methods. African Journal of Ecology : 1-9.

Kitanishi K. 2003 - Cultivation by the Baka hunter-gatherers in the tropical rain forest of Central Africa. Afr. Stud. Monogr. SI 28 : 143-157.

Mercader J. 2002 - Forest People: the role of African rainforest in human evolution and dispersal. Evolutionary Anthropology $11: 117-124$.

Mercader J. \& Brooks A. 2001 - Across forests and savannas: later stone age assemblage from lturi and Semiliki, Democratic Republic of Congo. Journal of Anthropological Research 57 (2) :197-217.

Mercader J., Runge F., Vrydcghs L., Doutrelepont H., Ewango C.E.N. \& Juan-Tressera J. 2000 Phytoliths from archaeological sites in the tropical forest of Ituri, Democratic Republic of Congo. Quaternary Research 54 : 102-112.

Moisel M. 1910 - Karte von Kamerun, 1/300.000 H4-Molundu. Berlin.

Nelson S.H. 1994 - Colonialism in the Congo Basin, 1880-1940. Athens, Ohio University, 279 p.

Ngansop T.M., Elvire H., Biye E.H., Fongnzossie E., Forbi P.F. \& Chimi D.C. 2019 - Using transect sampling to determine the distribution of some key non-timber forest products across habitat types near Boumba-Bek National Park, Southeast Cameroon. BMC Ecol 19 : 3. https://doi.org/ 10.1186/s12898-01- 0219-y (Accessed on 31August, 2020).

Nishida M. 1997 - The origin of cultivation from an ecological standpoint. Primate Research 3 (2) : 173-182 (in Japanese).

Redford K.H. 1992 - The empty forest. Bioscience 42 (6) : 412-422.

Richards P.W. 1996 - Tropical Rain Forest: An Ecological Study (second edition), Cambridge University Press, $575 \mathrm{p}$.

Roberts P. 2019 - Tropical Forests in Prehistory, History, and Modernity. Oxford, Oxford University Press, $350 \mathrm{p}$.

Sato H. 2001 - The potential of edible wild yams and yam-like plants as a staple food resource in the African tropical rain forest. Afr. Stud. Monogr. SI 26 : 123-134.

Sato H., Hayashi K., Inai H., Yamaguchi R., Kawamura K. \& Yamauchi T. 2014 - A controlled foraging trip in a communal forest of southeastern Cameroon. Afr. Stud. Monogr. SI 47 : 5-24.

Sommerville K. 2014 - Ivory: Power and Poaching in Africa. London, Hurst \& Company, 390 p.

Stern N. 2006 - The Economics of Climate Change: The Stern Review. Cambridge, Cambridge University Press, $716 \mathrm{p}$.

Tajeukem V.C., Fongzossie F.E., Kemeuze V.A. \& Nkongmeneck B.A. 2014 - Vegetation structure and species composition at the northern periphery of the Boumba-Bek National Park, southeastern Cameroon. Afr. Stud.Monogr. SI 49 : 13-46. 
Tanno T. 1976 - The Mbuti net-hunters in the Ituri Forest, Eastern Zaire: Their hunting activities and band composition. Kyoto University African Studies $10: 101-135$.

Tanno T. 1981 - Plant utilization of the Mbuti Pygmies: With special reference to their material culture and use of wild vegetable food. Afr. Stud. Monogr. $1: 1-53$.

Terashima H. 1983 - Mota and other hunting activities of the Mbuti archers: A socio-ecological study of subsistence technology. Afr. Stud. Monogr. 3 : 71-85.

Terashima H. 1985 - Variation and composition principles of the residence group (band) of the Mbuti Pygmies: beyond a typical/atypical dichotomy. Afr. Stud.Monogr. SI 4 : 103-120.

Terashima H \& Ichikawa M. 2003 - Comparative ethnobotany of the Mbuti and Efe huntergatherers in the Ituri Forest, DRC. Afr. Stud. Monogr. 25 (1-2) : 1-168.

Toda M. 2014 - People and social organizations in Gribe, southeastern Cameroon. Afr. Stud. Monogr. SI 49 : 13-168.

Toda M. \& Yasuoka. H. 2020 - Unreflective promotion of the non-timber forest product trade undermines the quality of life of the Baka: Implications of the Irvingia gabonensis kernel trade in southeast Cameroon. Afr. Stud. Monogr. SI $60: 85-98$.

United Nations 2007 - United Nations Declaration on the Rights of Indigenous Peoples. https:// www.un.org/development/desa/indigenouspeoples/wp-content/uploads/sites/ 19/2018/11/ UNDRIP_E_web.pdf accessed on 1 September, 2020.

Vansina J. 1990 - Paths in the Rainforest. Madison, Wisconshin, The University of Wisconsin Press, $428 \mathrm{p}$.

White L.J.T. 2001 - Forest-savanna dynamics and the origins of Marantaceae forest in central Gabon. In : Weber W., White L.J.T., Vedder A. \& Naughton-Treves L. (Ed.) African Rain Forest Ecology and Conservation. New Haven, Yale University Press : 165-182.

Wilkie D. \& Carpenter J.F. 1999 - Bushmeat hunting in the Congo Basin: An assessment of impacts and options for mitigation. Biodiversity and Conservation 8 : 927-955.

Wilmsen E. 1986 - Historic process in the political economy of the San. Sprache und Geschichte in Afrika 7 (2) : 413-432.

Wilmsen E. 1989 - Land Filled With Flies: A Political Economy of the Kalahari. University of Chicago Press, Chicago, $416 \mathrm{p}$.

Wrangham R. 1986 - Ecology and social relationships in two species of chimpanzees. In : Rubenstein D.I. \& Wrangham R.W. (Ed.), Ecological Aspects of Social Evolution. Princeton, Princeton University Press : 352-378.

Yasuoka H. 2006a - Long-term foraging expedition (molongo) among the Baka hunter-gatherers in the northwestern Congo Basin: With special reference to the "wild yam question." Human Ecology 34 (2) : 275-296.

Yasuoka H. 2006b. The sustainability of Duiker (Cephalophus spp.) hunting for the Baka huntergatherers in Southeastern Cameroon. Afr. Stud. Monogr. SI 33 : 95-120.

Yasuoka H. 2009a - The variety of forest vegetations in southeastern Cameroon, with special reference to the availability of wild yams for the forest hunter-gatherers. Afr. Stud. Monogr. 30 (2) : 89-119.

Yasuoka H. 2009b - Concentrated distribution of wild yam patches: Historical ecology and the subsistence of African rainforest hunter-gatherers. Human Ecology 37 : 577-587. 
Yasuoka H. 2012 - Fledging agriculturalists? Rethinking the adoption of cultivation by the Baka hunter-gatherers. Afr. Stud. Monogr. SI 43 : 85-114.

Young G. \& Turner T. 1985 - The Rise and Decline of the Zairian State. Madison, Wisconsin, University of Wisconsin Press, 500 p.

\section{NOTES}

1. The "forest peoples" in central Africa are comprised of hunter-gatherers and small-scale shifting cultivators. I will mainly focus on hunter-gatherers in this review, and mention about cultivators when they are relevant to the life of hunter-gatherers, or when comparisons are made between the two groups.

2. In a recent study, Hirai \& Yasuoka (2020) reported the abundance of Irvingia gabonensis nuts in the forest of southeastern Cameroon. The nuts are available from July to October, but only several percent of the total production is actually collected. If they were collected in a more intensive way, the nuts could comprise one of the major food resources in the rainy season, when few yam tubers are available (see also Gallois et al. [2020]).

3. Carrière (2002) had made similar research on selective sparing of trees in the swidden fields among the Ntumu farmers in southern Cameroon, and discussed about its long-term impact on the rainforest landscape.

4. The bushmeat trade now seems to be declining, owing to the pressure from international organizations to protect game animals and in order to avoid infectious diseases caused by wildlife, such as Ebola, Covid-19 and other zoonotic diseases.

5. The relative price of meat to cloths rose in 1985 when cheap cloths were imported from east African countries.

\section{ABSTRACTS}

Contemporary hunter-gatherers in central Africa face similar problems concerning their culture and environment: destruction of the forests that have been accommodating their unique forestbased culture, influences of market economy and consumerism, and nature conservation initiatives that restrict their extractive activities in protected areas. In order to cope with these problems, it is important to understand their life and culture in local ecological settings, as well as in historical and wider economic and political contexts. I will describe here three approaches that have been taken and developed by Japanese ecological anthropologists to the study of central African hunter-gatherers. The three approaches are (1) cultural ecology, which describes the way the hunter-gatherers perceive, understand and utilize the forest environment, (2) historical ecology, which shows how they modify the forest through interacting with it, and (3) political ecology, which analyzes how the economic and political situation influences their relationship with the forest. I will then examine the implications of the results from these approaches for addressing the current problems faced by the central African forest huntergatherers and their environment. 
Les chasseurs-cueilleurs contemporains d'Afrique centrale sont confrontés à des problèmes similaires en ce qui concerne leur culture ou leur environnement ; la destruction des forêts qui ont nourri leur culture unique, les influences de l'économie de marché et du consumérisme, et la conservation de la nature qui restreignent leurs activités d'extraction dans les aires protégées. Pour appréhender ces problèmes, il est important de comprendre leur vie et leur culture dans les contextes écologiques locaux, ainsi que leurs situations historiques, économiques et politiques dans une société plus large. Je décrirai ici trois approches qui ont été adoptées et développées par des anthropologues de l'environnement japonais pour l'étude des chasseurs-cueilleurs d'Afrique centrale. Les trois approches sont (1) l'écologie culturelle, qui décrit la façon dont les chasseurscueilleurs perçoivent, comprennent et utilisent l'environnement forestier, (2) l'écologie historique, qui montre comment ils modifient la forêt en interagissant avec elle, et (3) l'écologie politique, qui analyse comment la situation économique et politique influence leur rapport à la forêt. J'examinerai ensuite les résultats de ces différentes approches pour répondre aux problèmes actuels auxquels sont confrontés les chasseurs-cueilleurs forestiers centrafricains et leur environnement.

\section{INDEX}

Keywords: hunter-gatherers, tropical forests, cultural ecology, historical ecology, political ecology

Mots-clés: chasseurs-cueilleurs, forêts tropicales, écologie culturelle, écologie historique, écologie politique

\section{AUTHOR}

\section{MITSUO ICHIKAWA}

Professor Emeritus, Kyoto University 